\title{
Identifikasi Awal Model Akuifer pada Mata Air Umbulan dengan Menggunakan Geolistrik Konfigurasi Schlumberger
}

\author{
Tatas $^{1)}$, Mahendra A. M. ${ }^{2)}$, S. Kamilia Aziz ${ }^{1)}$, Amien Widodo ${ }^{3)}$ \\ ${ }^{1)}$ Program Studi Diploma Teknik Sipil FTSP ITS, Surabaya \\ 2)Jurusan Teknik Sipil FTSP ITS, Surabaya \\ ${ }^{3)}$ Jurusan Teknik Geofisika FTSP ITS, Surabaya \\ Email:tatas@ce.its.ac.id
}

\begin{abstract}
Drought is becoming one of the disasters that always happen every year in some parts of Indonesia. In 2011, Badan Nasional Penanggulangan Bencana (BNPB) stated that drought threatens national food production. One form of the drought is reduced discharge or even death springs. Umbulan is a spring that has considerable potential for the discharge of 4000-5000 liters/sec, can be used as a source of raw water. Associated with such a huge potency it is necessary to learn how geological structures as a basin for the groundwater (hydrogeology). It is to be used as a basis to study the behavior of water is the source of the Umbulan Spring. One of the methods that can be used to determine the hydrogeological structure is geo-electric based method. Based on the results of resistivity measurements, it can be concluded that the value of the resistivity of the rock making up the study area ranges from 1-4800 $\mathbf{\Omega m}$. Based on the results of geo-electric interpretation, rocks making up in the area of research are in the form of sand, tuffaceous sands, breccias, breccia sandy, sandy tuff and tuff. Layer which serves as barrier layer or water-resistant coating is tuff, sandy tuff, and lava. Layer that serves as the aquifer is sand, tuffaceous sand, sandy breccias, and breccia with depths between 25-125 meters.
\end{abstract}

Keywords: Umbulan, geo-electric, hydrogeology.

Abstrak

Bencana kekeringan, saat ini menjadi salah satu bencana yang selalu datang setiap tahun di beberapa wilayah Indonesia. Tahun 2011, Badan Nasional Penanggulangan Bencana (BNPB) menyatakan bahwa bencana kekeringan mengancam produksi pangan nasional. Salah satu bentuk dari bencana kekeringan tersebut adalah berkurangnya debit atau bahkan matinya mata air. Mata Air Umbulan merupakan mata air yang memiliki potensi yang cukup besar dengan debit sebesar 4000-5000 liter/detik, dapat dijadikan sebagai sumber air baku. Terkait dengan potensi yang sangat besar tersebut maka perlu dipelajari bagaimana struktur geologi yang menjadi wadah bagi air tanah tersebut (hidrogeologi). Hal tersebut untuk dijadikan sebagai dasar untuk mengetahui perilaku air yang menjadi sumber Mata Air Umbulan. Salah satu metode yang dapat digunakan untuk mengetahui struktur hidrogeologi adalah dengan menggunakan geolistrik. Berdasarkan hasil pengukuran resistivitas struktur batuan maka dapat diperoleh kesimpulan bahwa nilai resistivitas batuan penyusun pada area penelitian berkisar antara 1-4800 $\Omega \mathrm{m}$. Berdasarkan hasil interpretasi geolistrik, batuan penyusun area penelitian berupa pasir, pasir tufan, breksi, breksi berpasir, tuf berpasir dan tuf. Lapisan yang berfungsi sebagai penahan air atau lapisan kedap adalah lapisan tuf, tuf berpasir, dan lava. Lapisan yang berfungsi sebagai akifer adalah lapisan pasir, pasir tufan, breksi dan breksi berpasir dengan kedalaman antara 25-125 meter.

Kata kunci: Umbulan, geolistrik, hidrogeologi.

\section{Pendahuluan}

Bencana kekeringan yang dahulu tidak pernah terjadi di Indonesia, kenyataannya saat ini menjadi salah satu bencana yang selalu datang setiap tahun di bebe- rapa wilayah Indonesia. Pada tahun 2011, Badan Nasional Penanggulangan Bencana (BNPB) menyatakan bahwa bencana kekeringan mengancam produksi pangan nasional. Data yang dikeluarkan oleh Kementerian Pertanian me-

Jurnal APLIKASI: Media Informasi \& Komunikasi Aplikasi Teknik Sipil Terkini Halaman 35 
nunjukkan kekeringan sudah mencapai 95.851 hektare per Agustus 2011. Pada tahun 2011 tersebut, Jawa Timur menempati urutan keempat dalam hal luasan area pertanian yang mengalami kekeringan setelah Provinsi Sulawesi Selatan, Jawa Barat dan Nangroe Aceh Darussalam. Luasan area pertanian di Jawa Timur yang mengalami kekeringan 3.842 ha dengan luasan area pertanian yang mengalami puso 623 ha. Selain itu, peningkatan jumlah penduduk serta meningkatnya ekonomi masyarakat juga berimbas pada peningkatan kebutuhan air bersih. Kebutuhan air bersih tidak hanya untuk konsumsi rumah tangga, namun juga untuk kegiatan produktif lainnya seperti jual-beli air bersih, ataupun untuk kegiatan produksi skala industri. Dua kondisi, yaitu kekeringan dan kebutuhan air, yang saling berkaitan tersebut saat ini menjadi isu global yang sangat hangat dibicarakan terutama yang menyangkut perubahan iklim global.

Kota Surabaya dan beberapa kota satelitnya, seperti Sidoarjo, Pasuruan, dan Gresik merupakan kota industri yang padat jumlah penduduknya, tentunya memiliki kebutuhan yang tinggi akan air bersih. Saat ini, fokus pemerintah daerah dan pusat untuk mengatasi masalah air bersih yaitu dengan memanfaatkan sumber Mata Air Umbulan di Kecamatan Winongan, Kabupaten Pasuruan (lihat Gambar 1). Menurut catatan Puslitbang Sumber Daya Air, 2010, debit Mata Air Umbulan yang diukur sejak bulan Pebruari 2007 sampai dengan bulan Oktober 2008 mengalami penyusutan debit, yaitu dari $4.051 \mathrm{l} / \mathrm{s}$ menjadi 3.278 1/s (head pond). Sumber Mata Air
Umbulan ini direncanakan akan dimanfaatkan oleh 5 daerah yaitu Kabupaten Probolinggo, Kota Probolinggo, Kabupaten Sidoarjo, Kota Surabaya, dan Kabupaten Gresik.

Salah satu recharge area (daerah imbuhan) dari Mata Air Umbulan diduga dari kawasan Gunung Bromo. Secara umum, kawasan Gunung Bromo terbagi menjadi 2 kondisi, yaitu kawasan kaldera dan kawasan lereng gunung. Kawasan kaldera ini diduga merupakan kawasan imbuhan yang sangat berpengaruh besar pada Mata Air Umbulan karena bentuknya seperti mangkuk, sehingga air hujan yang mencapai kaldera ini 100\% akan terimbuh ke dalam tanah. Selain itu juga, kawasan lereng gunung juga diduga menjadi salah satu kawasan resapan air tanah bagi Mata Air Umbulan. Penelitian yang telah dilakukan di sekitar lokasi studi baru berupa identifikasi hidrogeologi di sekitar mata air (Seizarwati, dkk, 2012). Mata Air Umbulan dari akuifer bebas (pada kedalaman 0-20 meter). Akuifer tersebut diduga tidak menerus ke arah utara. Ujung lapisan tersebut lebih mendekat ke permukaan, sebagai penahan air menuju ke utara (Seizarwati, dkk, 2012). Selain lapisan tersebut juga terdapat lapisan akuifer bebas pada kedalaman 0-50 meter dengan bagian bawah lapisan breksi vulkanik (utara) dan lapisan kedap berupa lava (selatan). Selain itu, terdapat lapisan lava tebal yang mencapai 45 meter yang merupakan lapisan kedap sebagai pemisah akuifer bebas yang tipis dan akuifer tertekan yang tebal (Seizarwati, dkk, 2012).

Halaman 36 Jurnal APLIKASI: Media Informasi \& Komunikasi Aplikasi Teknik Sipil Terkini 


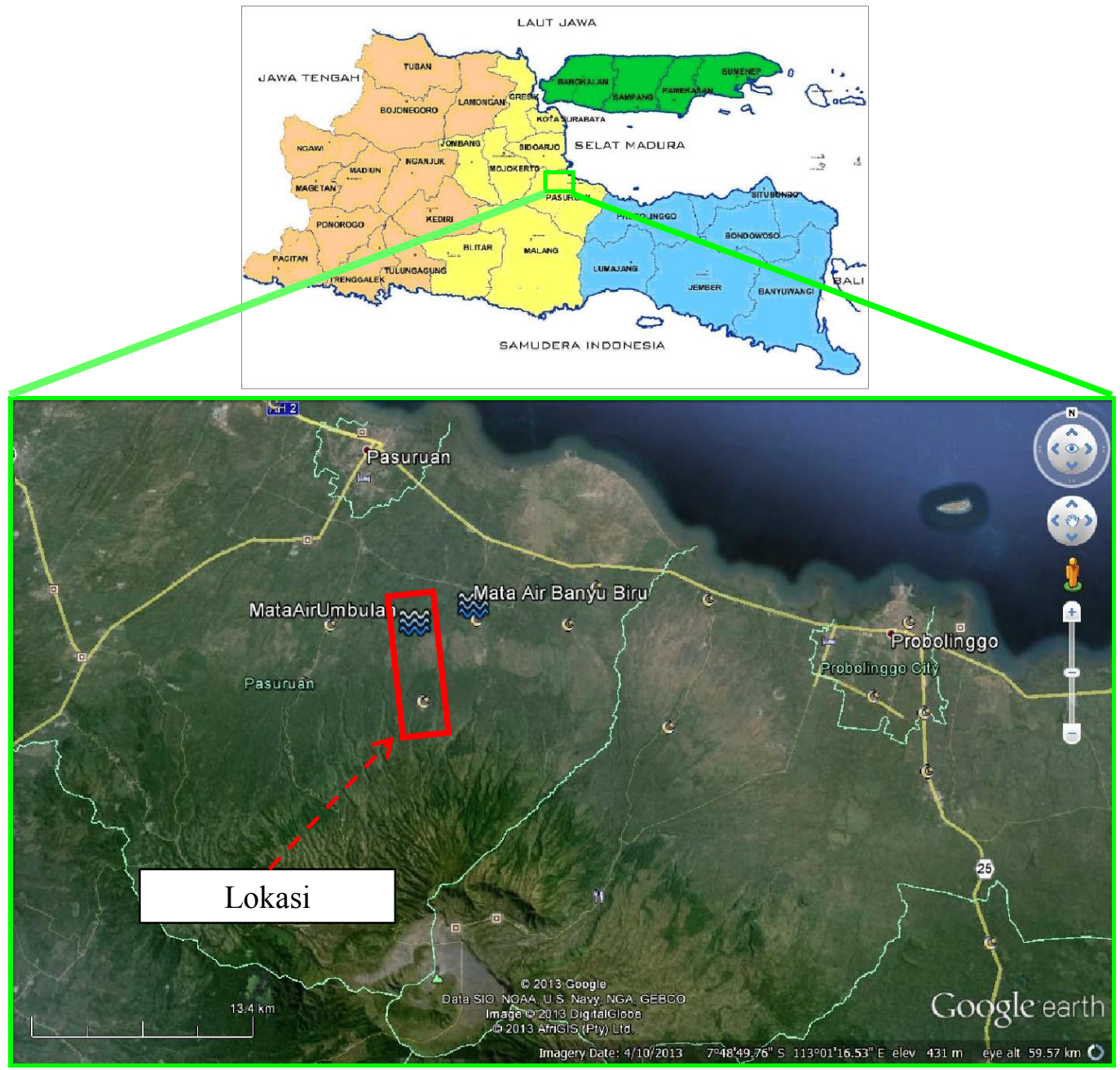

Gambar 1. Lokasi Mata Air Umbulan

Penelitian tersebut belum menggambarkan secara detail tipe hidrogeologi dari sekitar mata air ke arah pegunungan Bromo yang merupakan area resapan Mata Air Umbulan. Pada penelitian ini mencoba menggambarkan model hidrogeologi di sekitar Mata Air Umbulan dan setahap melangkah ke bagian area resapan.

Dengan mengetahui model hidrogeologi yang menuju arah ke arah selatan (pegunungan), maka akan dapat diketahui model aliran air yang berasal dari aream resapan di sekitar Pegunungan
Bromo, sehingga dapat digunakan untuk melakukan konservasi area resapan.

\section{Metodologi}

Lokasi penelitian di tiga desa pada dua kecamatan. Pengukuran geolistrik tahanan jenis dilakukan pada sisi jalan sepanjang jalan desa mengarah ke kawasan Gunung Bromo. Elevasi pengukuran geolistrik bervariasi antara $18-450$ meter dari permukaan laut.

Pada penelitian ini, digunakan alat geolistrik untuk menentukan hambatan jenis batuan. Pendeteksian ini meliputi

Jurnal APLIKASI: Media Informasi \& Komunikasi Aplikasi Teknik Sipil Terkini Halaman 37 
pengukuran potensial, arus, dan medan elektromagnetik yang terjadi dengan penginjeksian arus.

Metode geolistrik yang digunakan untuk mempelajari keadaan bawah permukaan bumi, pada penelitian ini adalah metode tahanan jenis (resistivitas). Asumsi awal, bahwa bumi bersifat elektris, sehingga batuan dan mineral yang mempunyai sifat berbeda dalam menghantarkan arus listrik dijadikan sebagai penafsiran jenis batuan/mineralnya. Perbedaan sifat hantaran listrik dipengaruhi oleh kelimpahan kandungan mineral-elektrolit padat-air serta keragaman tekstur, porositas, permeabilitas dan suhu. Gambar 2 merupakan kisaran nilai tahanan jenis (resistivitas) beberapa batuan.

Besaran fisik sebagai dasar metoda geolistrik tahanan jenis adalah nilai tahanan jenis dari batuan yang diketahui dengan mengalirkan arus searah atau arus bolak-balik berfrekuensi rendah. Untuk melakukan akuisisi data, ada beberapa cara yang dapat dilakukan tergantung kebutuhan dan target yang ingin didapatkan. Antara lain:

\section{a. Profiling}

Jarak pengukuran sepanjang garis pengukuran (profiling) selalu konstan atau sesuai luasan yang dibutuhkan (mapping) dengan jarak elektroda dibuat konstan.

\section{b. Vertical electrical sounding (VES)/ 1 dimensi}

Pengukuran dengan cara memperlebar jarak antar elektroda dengan titik tengah yang sama, pengukuran cara ini untuk mendapatkan variasi nilai resistivitas secara vertikal pada satu titik pengukuran.

\section{RESISTIVITY ( $\Omega . m)$}

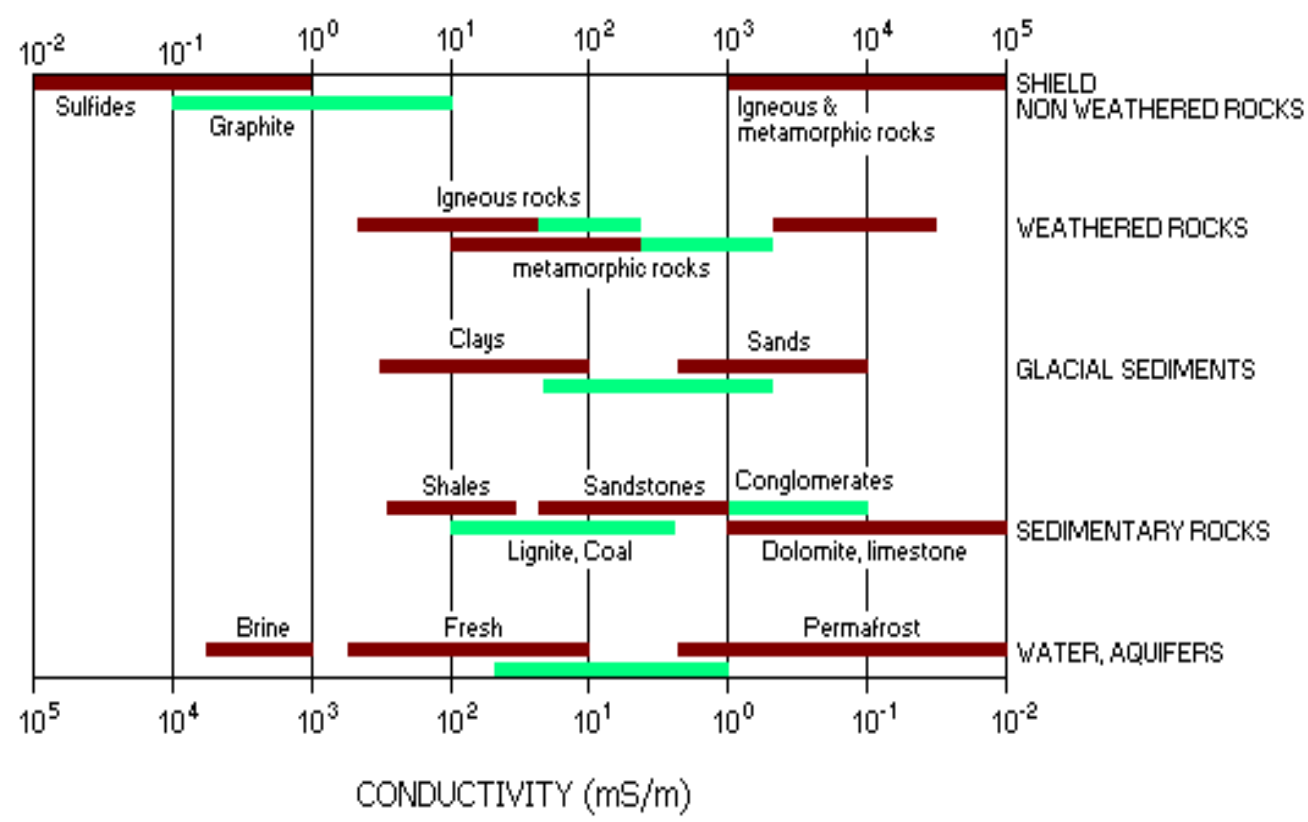

Gambar 2. Kisaran nilai tahanan jenis dari beberapa jenis batuan

Halaman 38 Jurnal APLIKASI: Media Informasi \& Komunikasi Aplikasi Teknik Sipil Terkini 
c. Dua dimensi

Pengukuran dengan cara memperlebar jarak antar elektroda dan menggeser titik tengah pengukuran sepanjang lintasan pengukuran sehingga diperoleh sebaran nilai resistivitas secara vertikal sepanjang lintasan pengukuran.

\section{d. Tiga dimensi}

Metode ini merupakan gabungan antara cara pengambilan data mapping dan 2 dimensi, yang akan didapatkan sebaran nilai resistivitas secara vertikal pada luasan area pengukuran.

Untuk melakukan keempat cara akuisisi geolistrik tersebut dalam penelitian ini menggunakan konfigurasi Schlumberger.

Elektroda yang digunakan pada konfigurasi ini berjumlah 4, 2 elektroda merupakan elektroda potensial, dan 2 elektroda lainnya merupakan elektroda penginjeksi arus (Gambar 3) dengan jarak elektroda arus jauh lebih besar dari jarak elektroda potensial. Untuk mendapatkan nilai resistivitas semu dari konfigurasi ini digunakan persamaan berikut:

$\rho_{a}=\frac{\pi\left(L^{2}-\ell^{2}\right)}{2 \ell} \frac{\Delta V}{I}$

dengan:

$\mathrm{V}=$ potensial

$\mathrm{I}=$ arus

$\mathrm{L}=$ jarak elektroda arus $(\mathrm{OA} / \mathrm{OB})$

$\ell=$ jarak elektroda potensial $(\mathrm{OM} /$ $\mathrm{ON}$ )

$\rho_{a}=$ nilai tahanan jenis semu (ohm.m)

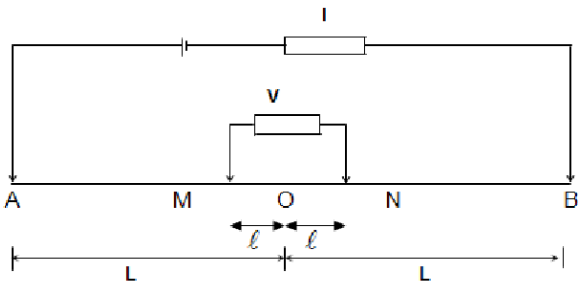

Gambar 3. Konfigurasi Schlumberger; $M$ \& $\mathrm{N}$ elektroda potensial; A\&B elektroda arus

\section{Hasil dan Pembahasan}

Secara geologi area penelitian disusun oleh Batuan Gunung Api Kuarter Tengah berasal dari tengger (Qpvt) dan Tuf Rabano (Qvtr). Lapisan Batuan Gunung Api Kuarter Tengah (Qpvt) terdiri dari Breksi gunung api, tuf, lava, aglomerat, dan lahar yang berasal dari pegunungan tengger. Untuk Lapisan Tuf Rabano (Qvtr) terdiri dari tuf pasiran, tuf batu apung, breksi tufan dan tuf halus abu. Gambar 4 adalah peta geologi regional area penelitian.

Berdasarkan peta hidrogeologi umum lembar X (Gambar 5), area penelitian memiliki akuifer produktif sedang sampai tinggi dengan penyebaran luas dan tergolong dalam jenis aliran akuifer yang melalui celahan dan ruang antar butir. Pada area akuifer produktifitas tinggi (Biru tua) memiliki kemenerusan dan kisaran kedalaman muka air tanah yang sangat beragam, debit sumur pada daerah ini umumnya lebih dari 5 liter tiap detiknya. Untuk area akuifer produktifitas sedang memiliki kemenerusan sangat beragam dan kedalaman muka air tanah bebas umumnya dalam dengan debit sumur umumnya kurang dari 5 liter tiap detik. Pada peta hidrogeologi juga ditunjukkan pada daerah penelitian

Jurnal APLIKASI: Media Informasi \& Komunikasi Aplikasi Teknik Sipil Terkini Halaman 39 
terdapat mata air yang dimungkinkan memiliki mata air dengan debit lebih besar dari 500 liter tiap detiknya. Dari peta geologi dan Hidrogeologi yang ada, dimungkinkan bahwa lapisan yang berfungsi sebagai akuifer adalah breksi/pasir tufan dengan tingkat kelulusan sedang. Yang dimungkinkan sebagai lapisan panahan air adalah tuf.

Pada lapisan Tuf Rabano (Qvtr) dilakukan dua titik pengukuran yaitu GEx9 dan GEx10. GEx9 memiliki elevasi 18 meter msl, pengukuran geolistrik pada titik ini dilakukan dengan target kedalaman 125 meter. Dari hasil pengolahan data didapatkan nilai tahanan jenis berkisar antara 3,5 $-320 \Omega \mathrm{m}$. Titik geolistrik tahanan jenis GEx10 memi- liki elevasi 24 meter msl, pengukuran didesain untuk menggambarkan struktur bawah permukaan sampai kedalaman 125 meter. Pada gambar 6 dapat dilihat hasil interpretasi data geolistrik GEx9 dan GEx10, lapisan yang berfungsi sebagai akuifer adalah pasir atau pasir tufan, sedangkan yang berfungsi sebagai lapisan kedap adalah tuf atau tuf berpasir.

Pengukuran geolistrik tahanan jenis pada Lapisan Batuan Gunung Api Kuarter Tengah Tengger (Qpvt) dilakukan pada 8 titik (GEx1, GEx2, GEx3, GEx4, GEx5, GEx6, GEx7, GEx8) dengan panjang lintasan 500 meter, letak titik pengukuran dapat dilihat pada gambar 7.
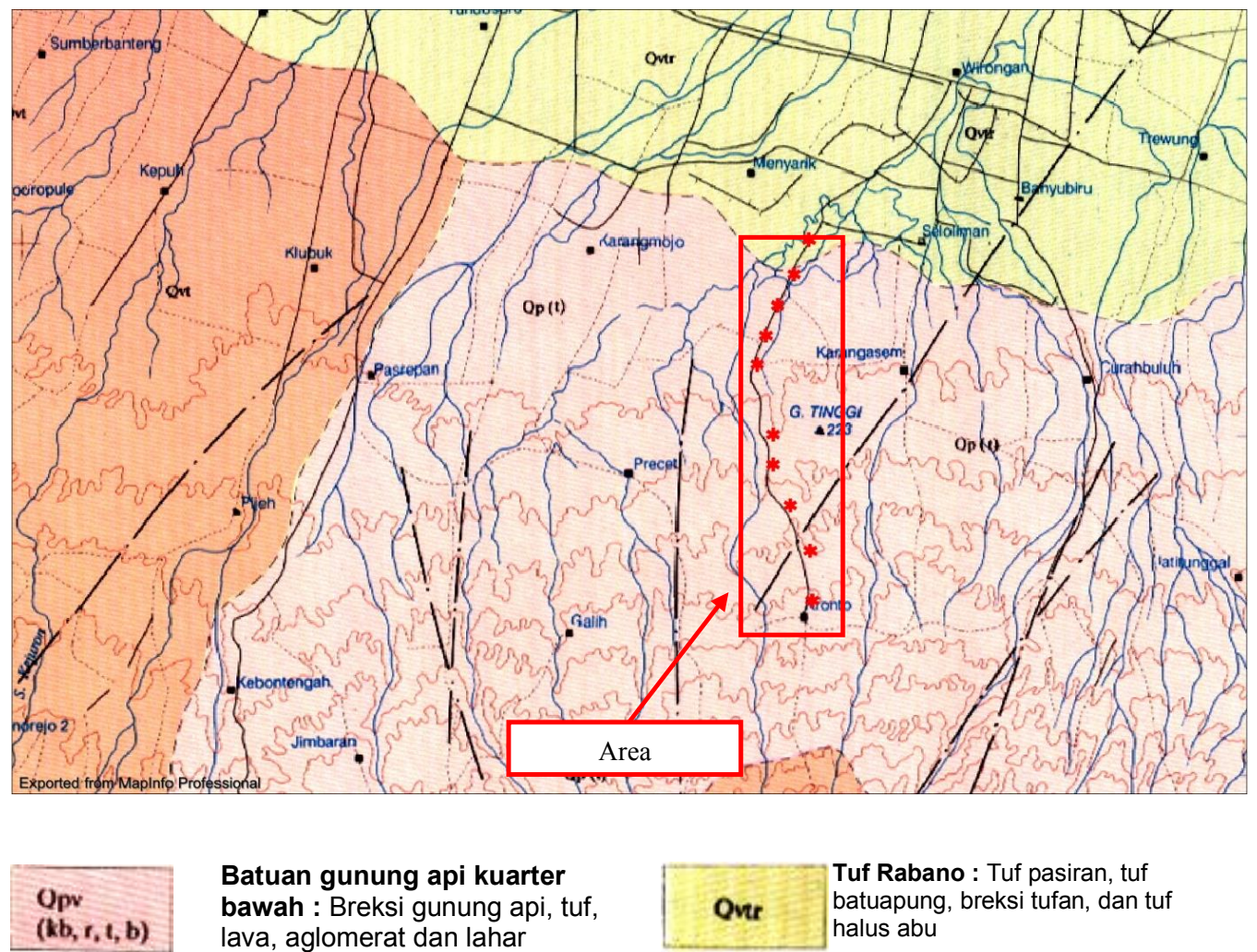

Batuan gunung api kuarter bawah : Breksi gunung api, tuf, lava, aglomerat dan lahar

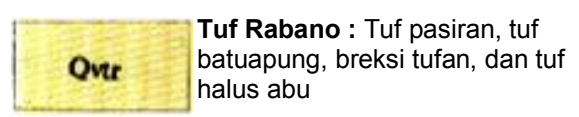

Gambar 4. Geologi area penelitian (Direktorat Geologi, 1963)

Halaman 40 Jurnal APLIKASI: Media Informasi \& Komunikasi Aplikasi Teknik Sipil Terkini 


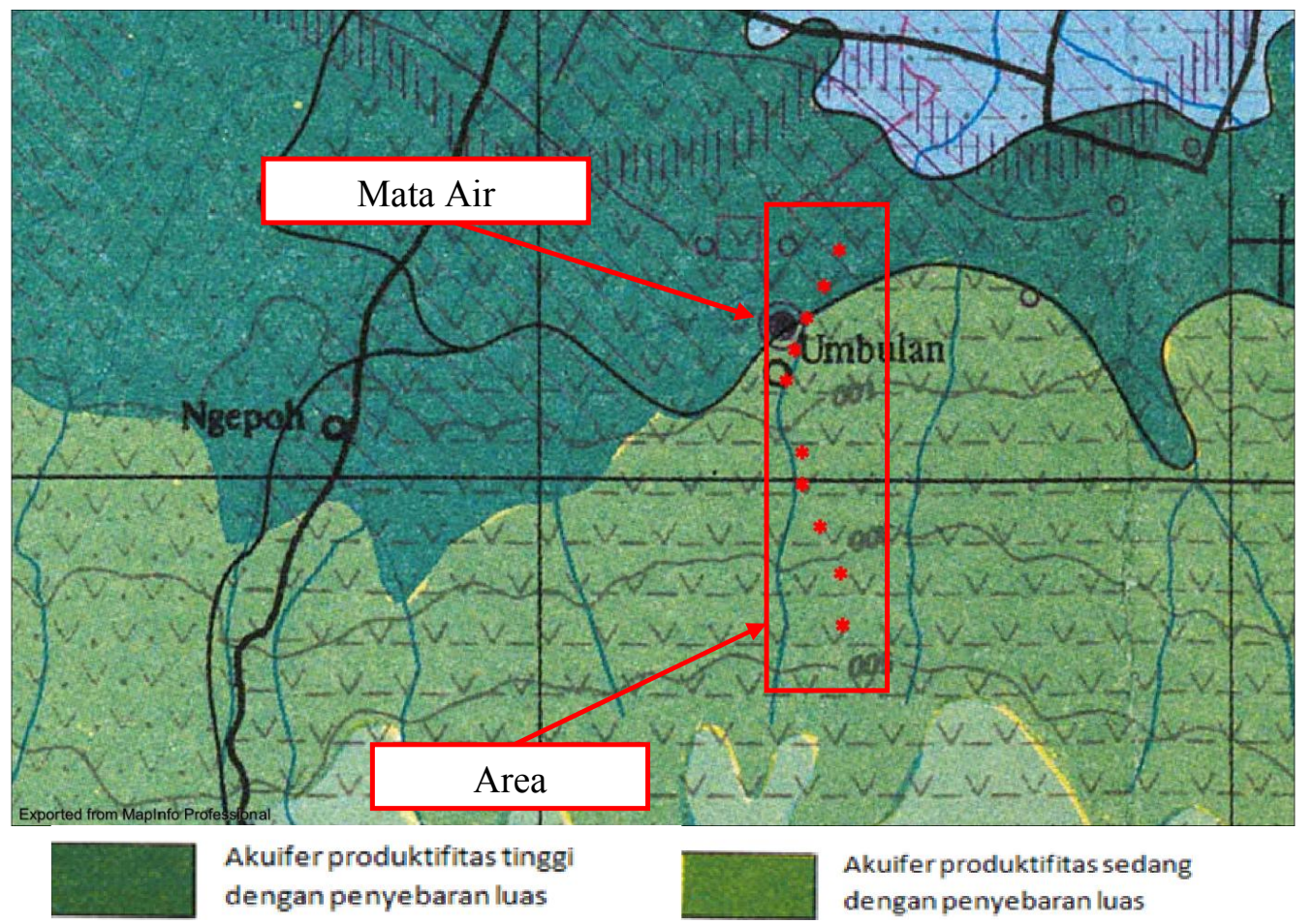

Gambar 5. Hidrogeologi area penelitian

Dari hasil pengolahan dan interpretasi data didapatkan jenis lapisan penyusun yang hampir sama pada setiap titik pengukuran, lapisan tersebut adalah Tuf, Tuf pasiran, Pasir, Pasir tuf, Breksi, Breksi berpasir, dan Lava. Pada lapisan batuan ini yang berfungsi sebagai lapisan kedap adalah Tuf, Tuf pasiran, dan Lava, sedangkan yang berfungsi sebagai lapisan akuifer adalah Breksi dan Breksi berpasir.

\section{Kesimpulan}

Nilai resistivitas batuan penyusun pada area penelitian berkisar antara $1 \Omega \mathrm{m}-$ $4800 \Omega \mathrm{m}$. Berdasarkan hasil interpretasi geolistrik, batuan penyusun area penelitian berupa Pasir, Pasir tufan, Breksi, Breksi berpasir, Tuf berpasir, dan Tuf. Lapisan yang berfungsi sebagai penahan air atau lapisan kedap adalah lapisan Tuf, Tuf berpasir, dan Lava. Lapisan yang berfungsi sebagai akuifer adalah lapisan Pasir, Pasir tufan, Breksi, dan Breksi berpasir dengan kedalaman antara 25-125 meter.

\section{Daftar Pustaka}

Puslitbang Sumber Daya Air. 2010. Laporan Akhir: Penelitian Hidrogeologi Daerah Umbulan, Bandung.

Badan standarisasi Nasional, SNI 032818-1992: Metode Eksplorasi Air Tanah dengan Geolistrik Susunan Schlumberger, Jakarta.

Seizarwati, W., Hutasoit, L. M., Ramdhan, A. M., 2013. Penyebab Penurunan Debit Mata Air Umbulan, Tesis, Institut Teknologi Bandung, Bandung (tidak dipublikasikan.

Jurnal APLIKASI: Media Informasi \& Komunikasi Aplikasi Teknik Sipil Terkini Halaman 41 


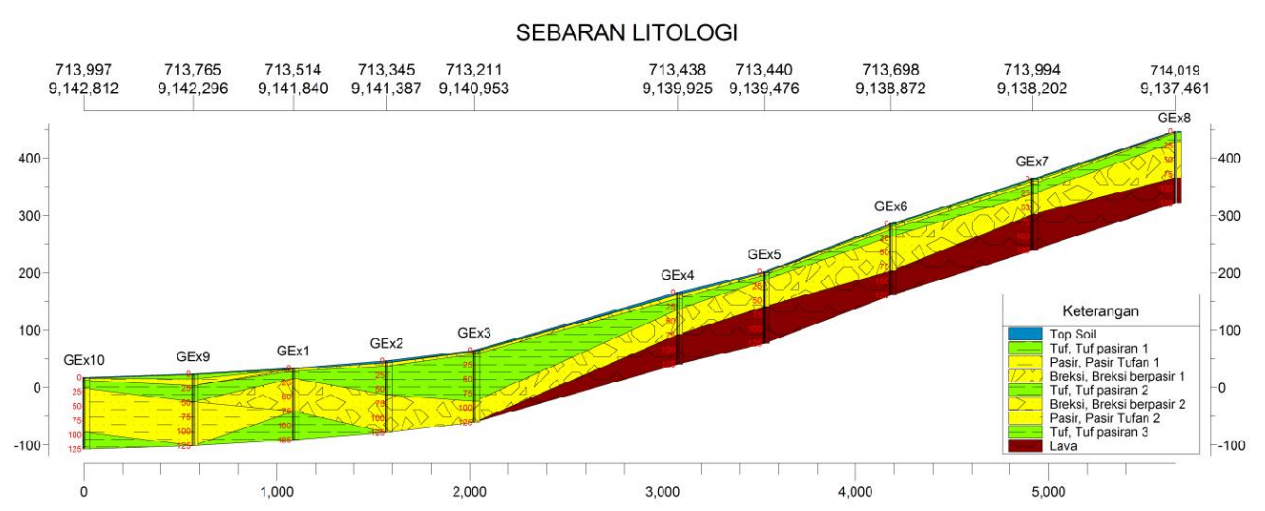

(a)


(b)

Gambar 6. (a) GEx1-10 dan (b) GEx1 dan 2, Kondisi bawah tanah hasil pengukuran geolistrik

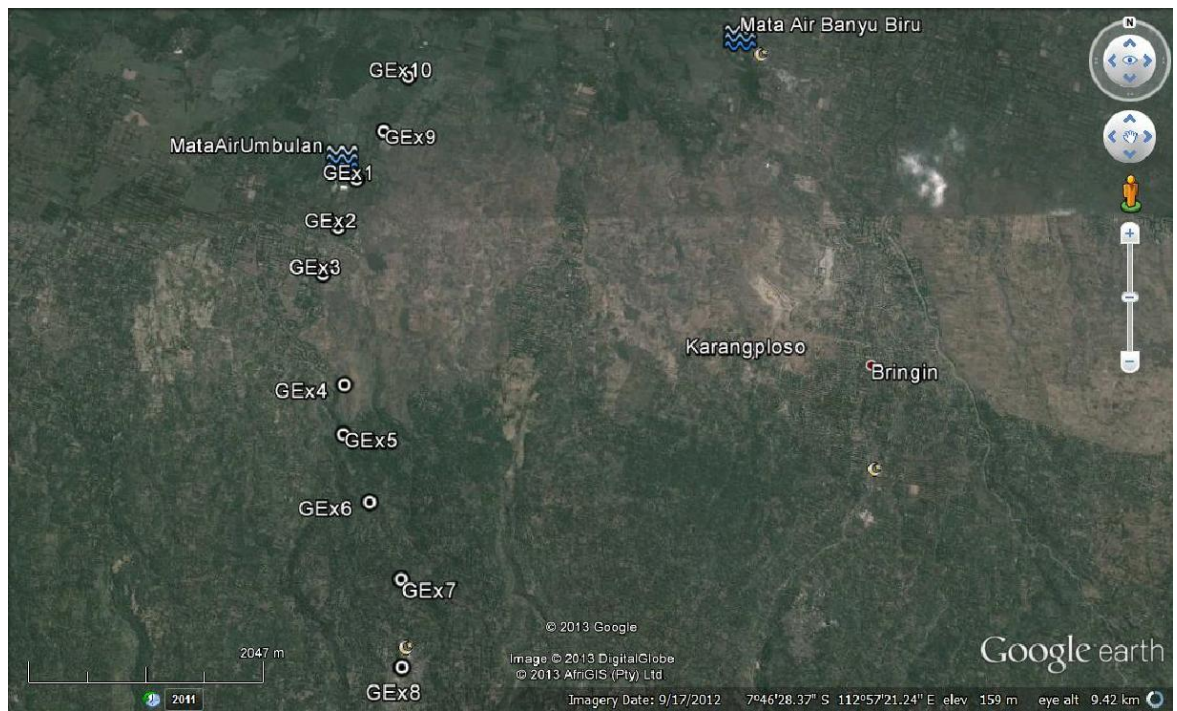

Gambar 7. Titik pengukuran geolistrik (Kode GE)

Halaman 42 Jurnal APLIKASI: Media Informasi \& Komunikasi Aplikasi Teknik Sipil Terkini 